STUDIA SOSIA RELIGIA

Volume 2 Nomor 1, Januari-Juni 2019

E-ISSN: 2622-2019

http://jurnal.uinsu.ac.id/index.php/ssr

\title{
TASHAWWUR ISLAM SEBAGAI ASAS PERDAMAIAN
}

\author{
Agusman Damanik \\ Fakultas Ushuluddin dan Studi Islam UIN Sumatera Utara \\ agusmandamanik515@yahoo.com
}

\begin{abstract}
Abstrak
Penelitian ini bertujuan ingin menelaah dan menganalisis sejauh mana Tashammur Islam sebagai asas perdamaian, tentunya dengan memahami terlebih dahulu makna tashawwur dan selanjutnya memahami berbagai dimensi-dimensi Tashawwur Islam diantaranya, dimensi teleologis, dimensi teologis, dimensi filosofis dan dimensi kausalitas atau sunnatullah. Kemudian dibahas tentang Tashawwur melalui tujuh karakteristik Islam yakni Rabbaniyah, Insaniyah, Syumuliyah, Alwaqi'iyah, Alwashitiyyah, Alwudhub dan Taubid Tashawwur wa tsabat. Dalam penelitian ini, pengumpulan data dilakukan dengan riset kepustakaan yang bersumber dari berbagai literatur yang relevan dengan masalah yang diteliti. Data yang telah terhimpun kemudian dianalisis dengan berbagai pendekatan terutama melalui pendekatan secara normatif filosofis.
\end{abstract}

Kata kunci : Islam, Perdamaian, Tashawnur

\section{Abstract}

This study aims to examine and analyze the extent of Islamic Tashawnur as the principle of peace. Of course, by first understanding the meaning of tashawnur and further understanding the various dimensions of Islamic Tashawnur, among them are the teleological dimensions, theological dimensions, philosophical dimensions and the dimensions of causality or sunnatullah. Then discussed about Tashawnur through seven characteristics of Islam, that is Rabbaniyah, Insaniyah, Syumuliyah, Alwaqi'iyah, Alwashitiyyah, Alwudhub and Taubid Tashawnur wa tsabat. This research is a library research, sourced from various literature relevant to the problem under study. The collected data is then analyzed using various approaches, especially through philosophical normative approaches.

Keyword: Islam, Peace, Tashawnur

\section{Pendahuluan}

Secara defenitif Islam dipahami kedamaiaan bahkan impilikasi kedamaian. Karena Islam senantiasa menghadirkan kedamaian tidak saja bagi manusia juga bagi seluruh alam semesta. Kendatipun ada sebagain yang meragukan Islam, disebabkan pandangan mereka terhadap umat Islam yang cenderung kontra perdamaian. Terutama dengan berbagai tindakan anarkisme dan 
terorisme oleh sebagian orang yang mengatasnamakan muslim. Dimana tindakan tersebut sangat bertolak belakang dengan identitas muslim sebagai pencinta kedamaian.

Muslim pencinta kedamaian merupakan implikasi dari kedamaian yang ada pada asmaul husna Allah yang maha salam.. Dengan kata lain, eksistensi keIslaman harus didasari dengan manifestasi kedamaian sang khaliq. Namun tetap saja menjadi pertanyaan di sebagian kita tentang bagaimana sebenarnya tashawwur atau rancang bangunan Islam sebagai pondasi dan pilar kedamaian, tulisan ini berupaya menjawab beberapa persoalan kontemporer tentang Islam dan perdamaian.

\section{Memahami Tashawwur Islam}

Tashawwur berasal dari kata tashawwara, yatashawwaru, tashawwuran yang berarti gambaran. Dalam bahasa kontemporer disebut dengan blue print, terdiri dari dua kata yakni blue berarti biru dan print yang berarti mencetak atau cetakan. Dalam kamus oxford dictionary kata blue print dipahami detailed description of plant, deskripsi yang mendetail tentang suatu rencana. Istilah blue print lebih identik dengan hal yang digunakan para arsitek untuk membuat rancang bangunan di kertas biru..

Blue print juga dipahami dengan sebuah rancangan yang dirumuskan dengan tujuan memberikan arahan terahadap kegiatan organisasi. Komunitas atau lembaga secar dinamis sehingga berbagai kegiatan senantiasa memiliki kesesuaian dengan tuntutan, tantangan serta kebutuhan lingkungan sekitar. Selain itu, blue printn adalah kerangka kerja yang terperinci sebagai landasan dalam pembuatan kebijakan yang meliputi tujuan, sasaran, penyusuanan strategi pelaksanaan program dan berorientasi pada kegiatan kerangka srta langkah-langkah maupun implementasi yang harus dilaksanakan oleh stiap unit di lingkungan kerja..

Selanjutnya kata Islam. Secara etimologi kata Islam berasal dari bahasa Arab yang berarti menyerahkan sesuatu kepada seseorang. Dalam konteks Islam, Muslim adalah orang yang memberikan keseluruhan jiwa raganya kepada Tuhan. Pengertian lain dari kata Islam yang dikemukakan oleh sejarawan bahasa adalah menyerahkan jiwa raga kepada Tuhan demi tujuan yang mulia. Penyerahan diri tersebut menunjukkan curahan cinta, suatu transformasi yang menyebabkan orang yang beriman menerima tanpa reserve (tanpa syarat) panggilan dari ajaran Tuhan. Bergerak menuju Allah berarti bergerak menuju absolut, menuju transendensi; merasa dipromosikan menuju eksistensi yang lebih tinggi. Dengan demikian, Muslim dalam Alquran seperti disebut Arkoun menunjuk kepada seseorang yang bertindak dalam ketaatan yang penuh rasa cinta kepada Tuhan (Syahrin, $2016: 20$ ). 
Berdasarkan pandangan Muhamad Iqbal dan Willam Hunt yang dituangkan dalam buku, A Concise Encyllopedia Of Islam, bahwa Islam berasal dari bahasa Arab yang bermakna damai. Damai oleh Muslim generasi pertama dipahami sebagai rasa damai, bebas dan kepercayaan polytheisme yang membingungkan. Kini ia telah damai perbuatannya direstui oleh Allah Swt. Tuhan Yang Maha Esa. Tidak lagi bingung seperti sebelumnya terhadap perbuatan baik yang dilakukan apakah disetujui oleh Tuhan yang banyak; seluruhnya atau masih sebagiannya yang dipercayai mempengaruhi kehidupan dan keselamatan mereka (Syahrin : 20).

Dari pengertian yang dipahami mengenai kata Islam dapat diketahui bahwa makna Aqidah Islam adalah selamat pasrah dan damai karena Islam adalah jalan keselamatan pedoman tentang kepasrahan dan pembawa kedamaian Allah berfirman katakanlah sesungguhnya yang diwahyukan kepadaku adalah bahwasanya Tuhan adalah Tuhan yang Esa maka hendaklah kamu berserah diri kepada-nya Surat Al Anbiya ayat 108.

Agama yang diajarkan Allah kepada manusia adalah Islam sebagaimana firman Allah dalam surat Ali Imran ayat 19. Hal ini menjelaskan bahwa agama yang mendapat perkenanan Tuhan adalah Islam sementara pada ayat lain disebutkan bahwa agama Islam sudah sempurna sebagaimana dijelaskan dalam surat Al-Maidah ayat 3.

Agama dalam dua ayat itu diartikan sebagai sikap tunduk dan patuh kepada Allah Swt. Itulah sebabnya ajaran Allah untuk semua nabi dan rasul adalah agar mereka terus mengajarkan keesaan Allah tauhid sebagai pencipta Penguasa pemelihara dan yang kuasa untuk meniadakannya.

Selain sebgai agama, Islam juga dimaknai dengan ajaran. Terkait Islam sebagai ajaran, tentunya sembernya adalah alqur'an yang diturunkan kepada nabi Muhammad saw dengan berbahasa arab yang kedudukannya mutawatir, memiliki ibadah dalam membacanya dimuali dengan surat alfatihah dan di akhiri dengan surat annas. (manna alqatthan, fi ulum alqur'an.....) dengan demikian tashawwur Islam adalah rancangan bangunan Islam baik sebagai agama maupun ajaran dengan berbagai tinjauan yakni teologis, teleologis, filosofis maupun kontekstual terutama yang berkaiatan dengan Islam sebagai pilar perdamaian.

\section{Dimensi-Dimensi Tashawwur Islam}

1. Dimensi Teleologis

Argumen terakhir dalam bagian ini apa yang biasa disebut argumen teleologis atau argumen from design (dalil al-inayah). Kata teleologis berhubungan dengan tujuan (telos) yang hendak dicapai. Jadi argumen ini menyatakan bahwa alam dicipta dengan tujuan tertentu, bukan 
secara kebetulan. Ada design (rancangan) dalam penciptaan ini untuk mencapai tujuan tersebut. Tentu saja pandangan ini cocok dengan ajaran Islam yang mengatakan"

"dan Dialah yang menciptakan langit dan bumi dengan benar. dan benarlah perkataan-Nya di waktu Dia mengatakan: "Jadilah, lalu terjadilab", dan di tangan-Nyalab segala kekuasaan di waktu sangkakala ditiup. Dia mengetahui yang ghaib dan yang nampak. dan Dialah yang Maha Bijaksana lagi Maha mengetabui”.

Boleh dikata argumen ini memiliki dua aspek (1) aspek design atau rancangan dan (2) aspek tujuan. Aspek design bisa kita lihat dari fenomena yang memiliki struktur sangat rapi. Dari dunia makro, seperti galaksi, hingga dunia mikro seperti atom, semua dibangun dengan sangat teratur dan harmonis. Sebagaimana galaksi dan tata surya, demikian juga atom, entitas yang sangat kecil ini, ternyata memiliki struktur yang rumit, mulai dari inti (nucleus) hingga orbit yang kadang terdiri dari beberapa elektron yang dengan kecepatan luar biasa mengelilingi intinya tanpa tabrakan. Dunia mikro ini mereflesikan keadaan dunia makro, seperti tata surya (solar system), dimana matahari dikelilingi oleh sejumlah palnet dengan ukuran yang berbeda-beda, tetapi dengan orbit yang telah ditentukan baik posisinya maupun kecepatannya.

Ambillah contoh bumi kita sendiri. Selama-lama berjuta-juta tahun bumi,sebagai salah satu planet yang mengitari matahari dengan rute yang pasti juga, tanpa kekurangan dan kelebihan sedikitpun,bahkan tidak sepermiliar detik dalam satu putarannnya, yang kita sebut setahun (Mulyadi : 25). Said Nursi menguraikan tentang teleologis, dengan mendemontrasikan keberadaan tuhan sebagai pencipta makhluk dan alam, juga pencipta siang dan malaam, matahari dan bulan, menghadirkan empat musim atau dua musim sesuai dengan geografis suatu negara, adanya hewan, tumbuh-tumbuhan, dan tujuan serta berbagai keadaan yang lain yang sangat sesuai dengan kebutuhan manusia serta makhluk-makhluk lainnya yang tetap berpijak pada kebijakannya (Nursi, $2009: 15)$.

Menurut Said Nursi, pada setiap kejadian tersebut, pasti ada invisible hand, yakni Tuhan. Sebagai contoh, ketika memahami kedua mata dari perspektif ilmu-ilmu kedokteran dengan detaildetail bagiannya yang tersusun secara kompleks dan begitu teratur untuk sebuah tujuan bijaksana, yakni melihat, maka saat itu juga manusia akan menyimpulkan bahwa kedua mata, merupakan produk Sang Pencipta yang Maha Cerdas (Zaprulkan, 1993 : 58).

Dalam kaitannya dengan keteraturan alam, al-ghazali berpandangan bahwa hal tersebut tidak jauh berbeda dengan sebuah rumah yang terdapat di dalamnya berbagai bahan yang dibutuhkan oleh sebuah rumah, demikian halnya dengan alam, dimana langit yang berada di atas seperti atab, bumi yang membentang seperti lantai, bintang-bintang gemerlapanseperti lampu, 
manusia sebagaai pemilik rumah, tentunya telah membuat rancangan bangunan yang teratur dan tersusun rapi dengan dikelilingi taman dan hewan peliharaan, jelas rumah yang demikian itu tidak akan bisa tercpta dengan sendirinya.alam pun demikian halnya, tidak bisa tercipta sendirinya pasti ada zat yang maha bijaksana yang menciptakan dan menjadikan alam yang demikian teratur dan tersusun rapi, zat itu tidak lain adalah tuhan (Al-Ghazali, 1993 : 15).

Teleologis pada hakikatnya menghadirkan kearifan tentang kekuasaan tuhan yang maha salam yang dengan kebijakan menganugerahkan kedamaian kepada seluruh makhluknya dan seluruh makhluk menuju ke arah satu kedamaian yakni Allah yang maha salam. Selain itu, Allah yang maha salam memancarkan kearifan kedamaian. Allah yang maha merancang kedamaian hingga merasuk ke hati para hambanya yang senantiasa berlumuran dengan dosa dan kemaksiatan.

\section{Dimensi Teologis}

Dalam kaitannya dengan tashawwur Islam pada dimensi teologis, dapat dikaji tentang perbuatan perbuatan manusia dan kekuasaan mutlak tuhan. Dalam kajian teologi dikenal dengan istilah qodaryah dan jabariyah. Qodariyah berasal dari bahasa Arab, yaitu dari kata Qodara yang artinya kemampuan dan kekuatan. Adapun secara terminologi atau istilah, Qodariyah adalah suatu aliran yang percaya bahwa segala tindakan manusia tidak diintervensi oleh Tuhan. Aliran ini berpandangan bahwa tiap-tiap orang adalah pencipta bagi segala perbuatannya, ia dapat berbuat sesuatu atau meninggalkannya atas kehendaknya sendiri (Al-Ghazali : 436).

Harun Nasution menjelaskan secara tegas bahwa kaum qadariyah berasal dari pengertian manusia mempunyai Qudrah atau kekuatan untuk melaksanakan kehendaknya dan bukan berasal dari pengertian bahwa manusia terpaksa tunduk pada qadar Tuhan (1986:31).

Selain itu, Amal Fathullah Zarkasyi menyebutkan bahwa aliran qodariyah disebut pula dengan Mazhab Al-Ikhtiyar (2006 : 56).

Ciri khusus aliran ini antara lain :

a. Kedudukan akal yang tinggi

b. Kebebasan manusia dalam kemauan dan perbuatan

c. Kebebasan berpikir hanya diikat oleh ajaran ajaran dasar dalam Alquran dan hadis yang sedikit jumlahnya.

d. Percaya pada sunnah dan kausalitas

e. Pengambil anti metaforis dan teks Wahyu

f. Adanya dinamika dalam sikap dan berpikir. 
Qodariyah tang dalam theologi barat disebut free weil juga berpandangan bahwa manusia mempunayai kebebasan untuk melakukan perbuatannya. Selaian manusia mempunyai kekuasaan atau daya pada tindakan-tindakannya. Free weil memberikan peran yang cukup besar kepada manusia di dalam hal menentukan, memilih, memilah, berpfikir dan memutuskan perbuatanperbuatannya, tampa campur tangan tuhan atau pembentukan wahyu, cukup akal saja yang dapat menentukan baik dan buruk atas perbuatannya sendiri (Sukiman, 2014 : 78).

Adapun aliran yang kedua adalah aliran jabariyah. Jabariyah berasal dari kata jabara yang berarti memaksa. Ketika Allah dikatakan mempunyai sifat al-jabbar, artinya Allah maha memaksa. Bahkan al-syahrastani menegaskan bahwa aliran jabariyah berarti menghilangkan perbuatan manusia dalam arti sesungguhnya dan menyandarkan kepada Allah. Dengan kata lain, manusia mengerjakan perbuatannya dengan terpaksa. Dalam istilah barat aliran ini disebut dengan fatalism atau predictination, yaitu bahwa aliran tentang perbuatan manusia telah ditentukan dari semula oleh qadha dan qadar tuhan (Rosihan, $2002: 77)$.

Berdasarkan kedua aliran ini, terutama dengan kaitannya eksistensi kedamaian. Manusia memiliki dua potensi kearifan dalam mewujudkan hal tersebut. Pertama, potensi dimana manusuia mampu menghadirkan kedamaian dengan kekuatan akal yang dimilikinya. Kedua, manusia juga memiliki potensi kesadaran bahwa untuk menghadirkan kedamaian harus senantiasa di bawah kekuasaan tuhan. Karena tuhan yang berkuasa untuk menganugerahkan kedamaian kepada para hambanya yang dikehendaki. Sebagaimana firman Allah dalam alqur'an surat aliimron ayat $26 "$

"Katakanlah: "Wahai Tuhan yang mempunyai kerajaan, Engkau berikan kerajaan kepada orang yang Engkau kehendaki dan Engkau cabut kerajaan dari orang yang Engkau kehendaki. Engkau muliakan orang yang Engkau kehendaki dan Engkau binakan orang yang Engkau kehendaki. di tangan Engkaulah segala kebajikan. Sesunggubnya Engkau Maha Kuasa atas segala sesuatu”.

3. Dimensi Filosofis.

Pada dimensi filoshopis, kedamaian terwujud dalam aksiologi filsafat atau yang lebih akrab disebut dengan filsafat nilai. Menurut Milton Rokeach nilai sebagai suatu keyakinan abadi yang menjadi rujukan bagi cara bertingkah laku atau tujuan akhir eksistensi yang merupakan referensi tentang konsepsi yang lebih baik atau konsepsi tentang segala sesuatu yang secara personal dan sosial dipandang lebih baik (AlRasyidin \& Amroeni, 2016 : 28).

Lain halnya dengan Jack R. Frankel, dimana beliau mendefinisikan nilai sebagai ide atau konsep yang menyebabkan seseorang memandang penting dalam hidupnya. sebagaimana 
kesalehan adalah hal yang yang dipandang penting bagi kehidupan keberagaman oleh hampir semua orang (Frankel, $1977:$ 6).

Adapun menurut Shaver dan Strong, dimana menurut mereka bahwa nilai merupakan sejumlah ukuran maupun prinsip-prinsip yang kita gunakan untuk menilai sesuatu yang berharga standar dan prinsip-prinsip tersebut digunakan untuk menilai segala sesuatu baik itu orang objek gagasan tindakan maupun situasi sehingga hal hal tersebut bisa dikatakan baik berharga dan layak atau tidak baik tidak berguna atau segala sesuatu yang berada diantara titik ekstrim keduanya (Shaver \& William,1982: 7).

Pengertian yang lain dijelaskan oleh Kosasih A Djahiri, dimana nilai memiliki dua makna, (1) Dimaknai sebagai harga yang diberikan seseorang atau kelompok orang terhadap sesuatu yang didasarkan pada tatanan nilai dan tatanan keyakinan yang ada dalam diri atau kelompok manusia yang bersangkutan. harga dimaksud adalah harga afektual ini harga yang menyangkut dunia afektif manusia. (2) isi pesan semangat atau jiwa kebermaknaan fungsi peran yang tersirat atau dibawakan sesuatu contoh al-qur'an memiliki nilai atau harga sebagai kitab yang memuat isi pesan Allah Swt yang bermakna sebagai kitab kumpulan wahyu ilahi sehingga mendapatkan kedudukan suci di hormati dan lain-lain (AlRasyidin \& Amroeini : 50).

A. Djahiri berpandangan pada dasarnya dunia ini adalah wadah nilai. karenanya tidak ada seorangpun yang hidup di dunia ini atau bebas nilai jika ada yang mengatakan bahwa saat ini banyak orang yang tidak memiliki rasa malu dan tidak cinta tanah air maka pernyataan pernyataan tersebut bukan berarti bahwa kini banyak orang yang hidup tanpa nilai sebab pada hakekatnya semua manusia memiliki rasa malu dan cinta tanah air dalam dirinya, hanya saja mungkin untuk saat ini atau pada situasi dan kondisi tertentu rasa malu dan cinta tanah air tersebut sedang mengalami disonansi atau melemah kualitasnya.

Demikian juga halnya jika saat ini banyak aparatur negara yang melakukan korupsi bukan berarti bahwa peraturan negara tersebut tidak memiliki nilai solidaritas dan cinta sesama mereka memiliki nilai-nilai tersebut namun ketika mereka melakukan korupsi nilai-nilai tersebut mengalami resonansi atau melemah kualitasnya. Dan secara umum nilai-nilai yang dianut dan menjadikan seseorang sebagai rujukan dalam menentukan standar prinsip atau harga tentang sesuatu bersumber pada etika, estetika, logika, agama, hukum dan budaya (AlRasyidin \& Amroeini : 50). 
4. Dimensi Kausalitas.

Pada dimensi kausalitas mengkaji tentang sebab dan akibat. Menurut Jean Mc. Kechnie bahwa Causality the interralation of couse and effect, principle that on thing can exist or happen without a cause' Kausalitas adalah hubungan dari sebab dan akibat dengan ketentuan bahwa tidak ada sesuatu terjadi tanpa sebab" (Jean, $1980: 288$ ).

Secara prinsipil, kausalitas meupakan proposisi primer yang diketahui manusia dalam kehidupan kesehari-harinya. Dimana prinsip ini menyatakan bahwa setiap sesuatu memiliki sebab. Dengan kata lain, segala sesuatu bergantung pada kausalitas (1) pembuktian realitas objektif persepsi indra (2) semua teori dan hukum ilmiah yang bersandarkan pada eksperimentasi, dan (3) kemungkinan dugaan dan kesimpulan-kesimpulannya dalam bidang filsafat maupun ilmiah apapun (Baqir, 2014 : 324).

Dalam memahami Islam, tentu hal yang urgens bila kita mengetahu tentang karakteristik ajaran Islam baik yang bersifat umum maupun yang bersifat khusus.Karakteristik ajaran Islam bersifat umum telah dijelaskan Yusuf Qaradhawi dalam bukunya Al-Khashais Al-'Ammah Li AlIslam,bahwa ada tujuh karakteristik ajaran Islam yang bersifat umum;

a. Rabbaniyah (karakteristik ketuhanan).

Karakteristik rabbaniyah mengandung arti bahwa agama Islam merupakan agama yang bersumber dari Allah swt, bukan bersumber dari manusia atau kreasi pemikiran manusia. Jika agama iskam bersumber dari tuhan, maka nabiMuhammad saw, sebagai rasulullah, dalam hal ini tidak membuat agama, akan tetapi beliau hanya pembawa atau penyampai ajaran Islam tersebut.dengan demikian setiap pembicaraannya atau perkataannya berdasarka wahyu yang diturunkan kepadanya.

Ajaran Islam itu bersumber dari Allah yang memiliki sifat maha sempurna, maka ajaran Islam akan senantiasa aktual dan kontekstual sepanjang masa. Dalam ajaran nya tidak akan pernah ditemukan revisi sedikitpun-sebgaiaman ditemukan dalam ajaran agama lain, yang dinamakan new statement (perjanjian baru), Allah selalu menjamin ajaran Islam ini selalu original (outentik/murni) (1994: 36).

\section{b. Insaniyah (karakteristik kemanusiaan).}

Agama Islam diturunkan untuk dibawa oleh seorang manusia yang dilengkapi dengan wahyu dan juga diperuntukkan bagi manusia. Oleh sebab itu Islam merupakan satu-satunya agama yang sesuai dengan fitrah manusia karena ajarannya sesuai dengan fitrah manusia. Maka tidak ada satupun ajarannya yang bertentangan dengan fitrah manusia, walau secara kasat mata ada orang 
yang menemukan hal-hal yang dianggap bertentangan, pasti hanya karena daya pemahaman manusia yang kurang tepat (1994: 59).

c. Syumuliyah (komprehensif).

Karakteristik jaran Islam selanjutnya adalah syumuliyah, agama Islam merupakan agama yang memiliki ajaran yang sangat lengkap, tidak hanya menggunakan satu aspek dan mengabaikan aspek lainnya. akan tetapi menyangkut seluruh aspek kehidupan manusia. Kelengkapan ajaran Islam itu tampak dlam berbagai bidang kehidupan mulai dari urusan pribadi, keluarga, masyarakat sampai pada persoalan berbangsa dan bernegara (1994: 117).

d. Al-Waqi'iyah (dapat direalisir).

Karakteristik lain ajaran Islamadalah al-waqi'iyah (dapat direalisir atau dapat dilaksanakan), hal ini menunjukkan bahwa Islam merupakan agama yang dapat diamalkan oleh manusia, atau dengan kata lain dapat direalisir dalam kehidupan sehari-hari. Bahkan ajaran Islam ini dapat diamalkan oleh manusia meskipun mereka berbeda latar belakang, apakah dia itu orang kaya, miskin, berjenis kelamin pria ataupun wanita, anak-anak, remaja, dewasa, berpendidikan tinggi atau berpendidikan rendah, bangsawan, rakyat biasa, berbeda suku adat istiadat dan lain sebagainya.

e. Al-Wasathiyah (moderat).

Karakteristik ajarn Islam juga bersifat wasathiyah (pertengaha atau keseimbangan). Allah swt menyebutkan bahwa umat Islam adalah ummatan wasathan umat yang seimbang dalam beramal baik yang terkait dengan peenuhan terhadap kebutuhan jasmani maupun kebutuhan rohani. Manusia memang membutuhkan konsep agama yang seimbang, hal ini karena tawazun (balance) merupakan sunnatullah (Abdussalam, T.t : 19).

f. Al-Wudhuh (jelas/mudah dipahami).

Termasuk dalam karakteristik penting lainnya dari ajaran Islam adalah tentang konsepnya ajaran yang jelas atau mudah dipahami (al-wudhub). Ajaran Islam ini jelas, tidak membuat umatnya menjadi bingung dalam memahami dan mengamalkan ajaran Islam. Dalam masalah akidah ( keyakinan) kepada Allah, konsep Islam begitu jelas sehingga dengan akidah yang mantap seorang muslim menjadi terikat dengan ketentuab Allah swt dan rasulnya. Konsep syari'ah atau hukumnya juga jelas sehingga umat Islam dapat melaksanakan peribadatan dengan baik dan mampu membedakan antara yang hak dengan yang bathil (Audah, $1985: 1$ ). 


\section{g. Menyatukan Antara Tathawwur (Transformasi) dan Tsabat.}

Selanjutnya karakteristik ajaran Islam adalah menyatukan antara transformasi dan konsistensi. Dengan kata lain, bahwa qaradhawi menjelaskan tentang dua golongan. Pertama, golongan yang lebih menekankan pada masalah keluwesan (fleksibilitas0 dan perkembangan (bersifat transformatif). Golongan kedua, golongan yang lebih menekankan sisi tsabat (konsistensi) dan abadi dalam syariat dan ajaran. Sehingga tidak ubahnya seperti berada di depan sebongkah batu karang yang kokoh, tidak bergerak atau melunak sedikitpun (Qardawi, 1994 : 241).

Selain tujuh karakateristik ajaran Islam secara umum, ada juga karakteristik ajaran Islam secara khusus. Khusus maksudnya pada aspek-aspek tertentu saja yang dalam pembahsannya merupkan bentuk interpretasi para ahli terhadap ajaran Islam (al-qur'an dan hadists) (Abuddin, 2010 : 79). Di antara karakteristik ajaran Islam yang bersifat khusus adalah;

a. Akidah,

Akidah dalam Islam keyakinan yang terpatri dalam hati sanubari seorang muslim tentang Allah yang wajib disembah, ucapan dengan lisan yang mantap dalam bentuk dua kalimat syahadat (syahadatain) perbuatan dengan amal saleh akidah yang demikianakan menggambarkan iman yang kuat kepada Allah, yakni niat, ucapan dan perbuatan, yang dikemukakan oleh orang yang beriman itu kecuali yang sejalan dengan kehendak Allah (Abuddin, 2010 : 85).

b. Ibadah.

Ibadah merupakan bentuk bakti seseorang kepada Allah Swt. yang didorong dan dibangkitkan oleh akidah, tauhid atau keimanan yang benar. Dengan demikian akidah atau keimanan menjadi pondasi dalam melaksaksanakan ibadah kepada Allah. Ibadah erat kaitannya dengan hal yang disukai dan diridhai Allah.sebagaimana pandangan ibnu taimiyah tentang ibadah, bahwa ibadah adalah segala hal yang disukai dan diridhai Allah dari perkataan dan perbuatan baik yang bersifat bathiniyah maupun zhahiriyah (Taimiyyah, $2005: 44$ ).

c. Bidang Kesehatan.

Hal yang terpenting dari karakteristik Islam dalam bidang kesehatan adalah prinsip menjaga kesehatan itu lebih utama daripada mengobati. Upaya menjaga kesehatan dengan menekankan pentingnya kebersihan lahir dan bathin.

d. Bidang Sosial.

Karakteristik ajaran Islam dalam bidang sosial menjadi hal yang sangat menarik karena ajaran Islam (al-qur'an) dalam bidang sosial ini sangat menonjol.. Hal ini terjadi karena semua ajaran Islam yang diturunkan kepada nabi Muhammad saw. Adalah untuk kesejahteraan sosial. 
Setelah menjelaskan tentang hakekat Islam, selanjutnya menjelaskan tentang perdamaian.Kata damai adalah antonim dari kata konflik, permusuhan, perseteruan, sengketa, pertengkaran, perselisihan dan tikai. Kendati demikian dalam hukum logika biner keberadaan atau ketiadaan salah satu merupakan keberadaan dan sekaligus ketiadaan yang lain. Damai tidak akan ada jika tak ada konflik. Damai menjadi ada hanya karena konflik juga mengada. Ketika damai dinegasikan hadirlah konflik. Jika konflik dinegasikan hadirlah damai. Keduanya adalah dua sisi pada mata uang satu.

Konflik sendiri sering diartikan sebagai tidak bertemunya dua atau lebih tujuan (Mitscel, 1981 : 12). Konflik adalah tidak seimbangnya hubungan- hubungan status social, kekayaan akses terhadap sumber kuasa dan kekuasaan yang berakibat pada munculnya berbagai problematika seperti diskriminasi kriminalitas pengangguran dan kemiskinan.

Damai adalah cerminan dari terkelolanya konflik.Damai bukanlah semata-mata ketiadaan perang, karena perdamaian yang sejati adalah damai yang dinamis, antisipatif dan berjangka waktu panjang. Damai sejati bisa terwujud manakala nilai-nilai kemanusiaan universal telah mengakar di segala lini, mulai dari kehidupan praktis keluarga, sekolah, komunitas masyarakat hingga Negara.

Layaknya Ying dan Yang, hubungan antara damai dan konflik akan berlangsung secara terus-menerus sebagai sebuah siklus kehidupan. Konflik dan damai sebagai realitas sosial akan selalu ada dalam diri manusia secara personal maupun kehidupan bersama dalam sebuah masyarakat. Menurut Ritzer konflik tidak dapat dipisahkan dari konsensus karena konflik dapat menyumbang sesuatu untuk perdamaian, bahkan konflik juga mendorong komunikasi dan konsensus dalam rangka integrasi (Ritzer, 2005 : 153).

Secara etimologis istilah perdamaian diterjemahkan dan dilafalkan secara berbeda sesuai konstruksi bahasa dan tradisi masyarakat masing-masing. Contohnya seperti ini, masyarakat Jerman memiliki istilah friede Bangladesh mengenai istilah Shanti dan Jepang menyebutnya heiwa. Masyarakat Indonesia sendiri menggunakan istilah damai yang sering diartikan sebagai kondisi Harmoni dan tentram. Meski demikian, masing-masing daerah di Indonesia memiliki istilah yang beraneka. Orang Jawa menyebut rukun ,Batak menyebut dame, Gayo menyebut dame dan lain sebagainya.

Dalam Islam, kata Islam sendiri merupakan derivasi dari kata Assalam yang berarti perdamaian bahkan umat Islam dianjurkan menyapa sesama muslim dengan Assalamualaikum, Semoga keselamatan senantiasa teruntuk dirimu. di Tiongkok dan India perdamaian diposisikan sebagai sifat dasar manusia. Lao-Tse, pendiri Taoisme menyatakan bahwa kekuatan militer 
(kekerasan) bukanlah tao atau jalan. Dalam Konfucius, manusia ditekankan untuk memelihara keharmonisan dan keseimbangan. Bhagavad Gita dalam epos Mahabarata juga menceritakan wejangan Sri Kresna kepada Arjuna tentang mengutamakan perdamaian.

Hal penting yang bisa ditarik benang merah dari uraian diatas adalah proses dan strategi perdamaian merupakan upaya mengelola konflik identitas dan kepentingan. Perdamaian adalah sebuah proses dan strategi perdamaian menuju kondisi hubungan sosial yang ditandai dengan ketiadaan konflik kekerasan kesalahpahaman dan intoleran strategi perdamaian dengan dialog Anti Kekerasan mampu menjadi karakter masyarakat demi kemaslahatan bersama.

lantas Bagaimana pemikiran mereka? kalau kita simak salah seorang pemikir Galtung membedakan antara perdamaian positif peace dan perdamaian negatif peace. Sementara itu webel memiliki istilah yang maknanya lebih kurang sama dengan perdamaian positif memiliki titik perdamaian positif berarti terpenuhinya rasa aman dan keadilan ekonomi dari sistem yang berlaku sampai terhapusnya diskriminasi ras etnis dan agama oleh struktur sosial.

Perdamaian positif tidak hanya berkaitan dengan usaha mereduksi kekerasan langsung Tetapi lebih kepada pengembangan pengembangan sosial secara vertikal yang bertanggung jawab terhadap hubungan-hubungan hirarkis di antara orang-orang. konsep perdamaian positif positif didasarkan pada pemahaman dasar dari kondisi kondisi sosial cara menghapus kekerasan struktural yang melampaui kekerasan langsung (Hoowon, 2003 : 25).

Makna damai sebagaimana diuraikan di atas membawa dampak dalam strategi adanya upaya perubahan terhadap struktur sosial yang diskriminatif. Oleh sebab itu, tuntutan persamaan (equality) dalam mendapatkan perlakuan oleh segala sistem dan struktur yang ada dalam ekonomi politik maupun sosial merupakan strategi yang bisa dijalankan dalam upaya mewujudkan perdamaian positif.

Secara prinsip Baros dan Weber menekankan bahwa perdamaian positif adalah sebuah kondisi yang dipenuhi oleh keadilan sosial (social Justice).Keadilan sosial itu sendiri didefinisikan secara berbeda oleh setiap masyarakat. Bagi masyarakat kapitalis liberalis seperti Amerika Serikat keadilan sosial melalui kebebasan berekonomi berpolitik dan gaya hidup sedangkan dalam masyarakat sosialis keadilan sosial merujuk pada keamanan sosial ekonomi melalui distribusi kesejahteraan dalam masyarakat meski berbeda definisi keadilan sosial ini secara prinsip adalah sama yakni terpenuhinya kesejahteraan sosial ekonomi budaya dan politik.

Selanjutnya adalah perdamaian negatif-negatif perdamaian jenis ini fokus pada tidak adanya kekerasan langsung seperti perang pertikaian perselisihan dan sejenisnya dalam 
mengupayakan perdamaian negatif pencegahan Tindak tindak kekerasan melalui jalur negosiasi atau mediasi dapat menjadi pilihan ketimbang pendekatan fisik total senjata total di mana misalnya dapat mereduksi potensi kekerasan bersenjata pada masa mendatang dalam perkembangannya menciptakan ketergantungan secara sosial dan ekonomi antar komunitas atau kelompok bisa menjadi salah satu strategi untuk mengurangi kekerasan langsung dalam situasi konflik antar komunitas(Hoowon : 24).

Baros dan Weber menyatakan bahwa perdamaian negatif berangkat dari pandangan realis yang meyakini bahwa perdamaian ditimbang dari ketiadaan perang perspektif ini memandang bahwa perdamaian bisa ditemukan kapan saja ketika tidak dapat uang atau segala bentuk kekerasan langsung yang terorganisasi. maka perdamaian filantropi Firaun merupakan bentuk parlemen negatif karena tidak adanya serangan terhadap negara lain ketika Imperium Romawi menahan ekspansi militer nya juga tidak bisa disebut perdamaian negatif meski didasarkan pada represi sosial politik.

Konsep perdamaian negatif kemudian memunculkan konsep pembangunan perdamaian negatif seperti diplomasi negosiasi dan resolusi konflik beberapa kalangan menyatakan bahwa perdamaian negatif perlu diupayakan meski harus menggunakan kekuatan militer pertahanan negara dan regional dalam pengertian hadirnya tentara dan persenjataan yang kuat juga termasuk dalam bidang perdamaian negatif

Melampaui second perdamaian negatif dan positif pada dan menyeluruh merupakan upaya menyatukan konsep perdamaian positif dan negatif pandangan perdamaian menyeluruh adalah usaha mengontrol dan mengelola kehidupan secara terus-menerus dari pada saat dengan mereduksi seluruh konsep pada bentuk-bentuk yang sederhana perdamaian ini merupakan pencarian biner atau perdamaian komunal dengan ketiadaan kekerasan yang terorganisasi.

Perdamaian menyeluruh menjadi narasi besar dalam membangun perdamaian 1996 menciptakan konsep transformasi konflik konflik transformation sebagai generasi pembangunan perdamaian ini transformasi konflik merupakan proses sosial politik yang menyertai aksi-aksi kedamaian negatif dan pada gilirannya akan membentuk sistem perdamaian positif

Seorang pemikir muslim Abdul Aziz Said, (2001 : 17) menyebutkan lima pendekatan Islam terhadap perdamaian:

a. Pertama, pendekatan kekuatan politik atau damai melalui paksaan kekuasaan. Pendekatan ini menempatkan negara sebagai salah satu Pranata yang mampu menciptakan perdamaian pendekatan politik Islam diyakini mampu mengantarkan masyarakat kearah kedamaian 
dalam konteks ini diyakini bahwa praktik dan nilai kedamaian dapat diwujudkan melalui imperatif sebuah negara Islam.

b. Kedua, pendekatan tatanan dunia atau damai melalui kekuatan hukum. Pendekatan yg menjadikan Islam sebagai paradigma etika dan pandangan hidup bagi perwujudan nilainilai keIslaman yang senantiasa berpihak pada nilai-nilai kedamaian dan universalitas. Dalam konteks damai diartikan sebagai sebuah kondisi ketika nilai- nilai keIslaman seperti keadilan, kemanusiaan, kejujuran, kesamaan dan kebersamaan tumbuh dan berkembang di tengah masyarakat.

c. Ketiga, pendekatan damai melalui kekuatan komunikasi. Model ini mengungkapkan pentingnya kemampuan komunikasi dalam menciptakan kedamaian. Beberapa praktik komunikasi efektif dalam Islam telah ditunjukkan melalui pendekatan rekonsiliasi (shulb), mediasi (wasatha) dan arbitrase (tabkim).

d. Keempat, pendekatan damai melalui kekuatan kehendak tidak melakukan sesuatu yang berbasis kekerasan. Pendekatan ini menegaskan bahwa ketika Islam melarang tindakan represif, kekerasan, tirani dan ketidakadilan, sebenarnya Islam mengajak untuk bertindak hal-hal yang berlawanan dengan yang dilarang tersebut yaitu tindakan damai kekerasan inilah sebenarnya yang sesuai dengan martabat kemanusiaan yang menjunjung nilai-nilai yang menantang tindak kekerasan dan pemaksaan.

e. Kelima, pendekatan transformasi damai melalui kekuatan cinta. Pendekatan Islam terhadap perdamaian dipungkasi dengan paradigma transformasi ke dalam hati dan pikiran manusia akan nilai-nilai kedamaian. Islam melalui praktik tasawuf mengajarkan bahwa damai dapat terwujud melalui kesadaran akan harmoni pengalaman keberagamaan dan penghayatan nilai kasih diyakini mampu mengantarkan seseorang bersama dalam kedamaian yang abadi.

Ditarik dari seluruh penjelasan di atas ada sebuah catatan penting yang bisa kita ambil dalam upaya membangun perdamaian yang harus dilakukan sesungguhnya adalah memahami faktor-faktor yang mempengaruhi ekspor ataupun damai dan mekanisme yang ditempuh untuk menjaga suasana damai faktor-faktor yang mempengaruhi perdamaian antara lain struktur kultur identitas dan segala faktor yang langsung ataupun tidak langsung terkait dengan potensi perdamaian sedangkan aktor adalah sebuah anggota masyarakat dengan ujung tombaknya terletak pada pucuk pucuk pimpinan Pimpin dalam segala hal ini Serta agen-agen perdamaian yang memiliki pengetahuan dalam membangun perdamaian mekanisme yang dapat dilakukan antara 
lain membentuk sistem siaga Dini ialah warning system untuk mencegah kemungkinan terjadinya konflik dan tetap menjaga situasi damai dalam berbagai kelompok wilayah dan situasi dengan mekanisme yang dapat diatur sesuai dengan kondisi masing-masing.

Penciptaan semesta ini dilakukan atas dasar cinta. Cinta pulalah yang mendorong penciptaan Nabi Adam as sebagai manusia Pertama. cintakan membawa manusia ke dalam fitrah kasih dan damai. Islam ada dalam titik fitrah cinta ini. Dalam banyak literatur Islam dikenal sebagai agama fitrah (din alfitrab). Pemahaman ini didasarkan atas dua hal; pertama, agama Islam mengajarkan pengakuan dan penyerahan diri kepada Allah Swta sejalan dengan kecenderungan manusia untuk mencari Tuhannya. Kedua, Islam sesuai dan selaras dengan sifat kejadian dan kodrat manusia.

\section{Penutup}

Berdasarkan kajian diatas, dapat disimpulkan beberapa hal bahwa;

1. Tashawwur Islam adalah rancangan bangunan Islam baik sebagai agama maupun ajaran dengan berbagai tinjauan yakni teologis, teleologis, filosofis maupun kontekstual terutama yang berkaiatan dengan Islam sebagai pilar perdamaian.

2. Adapun dimensi-dimensi Tashawwur Islam yaitu; Dimensi Teleologis, Dimensi Teologis, Dimensi Filosofis dan Dimensi Kausalitas atau Sunnatullah.

3. Tashawwur Islam sebagai Asas perdamaian dengan 7 karakteristik yakni Rabbaniyah, Insaniyah, Syumuliyah, Alwaqi'iyah, Alwashitiyyah, Alwudhuh dan Taubid Tashawnur wa tsabat

\section{Daftar Pustaka}

Abdussalam Alhiras, Al-Islam Dinul Wasathiyyah Wal Fadhail Wal Qoyyim Al-khalidah, Wazaratul Auqaf assaudiyah, jilid II) .

Abdul Qadir Audah, Al-Islam Baina Jahli Abnaibi Wa 'Ajz̨i Ulamaibi, Al-Ittihadiyah Al-Islamiyah, 1985.

Abdul Azzis Said, Peace and Conflict: Resolution In Islam: Precept andPractice, New York; University Of America, 2001.

Abuddin Nata, Metodologi Studi Islam, Jakarta, Rajawali Press, 2010.

Abu Hamid Alghazali, Ibya 'Ulumuddin, Jilid II (Beirut, Dar Da'wah, tth)

Ali Syariati, On The Sociology Of Islam, Barkeley, Mizan Press, 1979.

Chris Mitscel, The Structure of internasional Conflict, London, MacMillan, 1981.

George Ritzer, Modern Sosiological Theory, New York, The McGraw-Hill Companies, 2005. 
Hasan Bakti Nasution, Metodologi Studi Pemikiran Islam: Kalam, Filsafat, Islam, Tasawnf, Tareqat, Perdana Publishing, Medan, 2016.

Hoowon Jeong, Peace And Comflict-Studies : An Inttuduction, London: Ashgate Publishing, Company, 2003

Ibnu Taimiyah, Al-Ubudiyah, Al-Maktab Al-Islamy, beirut, 2005.

Sukiman, Pemikiran Teologi Islam Modern Joesoef Sou'yb, IAIN Press, Medan, 2014.

Syahrin Harahap, Jalan Islam: Menuju Muslim paripurna, Prenadamedia, Jakarta, 2016.

Yunasril Ali, Buku Induk Rahasia dan Makna Ibadah, Zaman, Jakarta, 2012.

Yusuf Qaradhawi, al-khashais al-'ammah li al Islam, beirut, Muassah al risalah, terj.rofi Munawwar dan tajuddin, karakteristik Islam kajian Analitik, Risalah Gusti, Surabaya, 1994. 